Marquette University

e-Publications@Marquette

$2-1-2015$

\title{
The Current State of Physical Therapy Pain Curricula in the United States: A Faculty Survey
}

Marie K. Hoeger Bement

Marquette University, mariehoeger.bement@marquette.edu

Kathleen A. Sluka

University of Iowa

Accepted version. Journal of Pain, Vol. 16, No. 2 (February 2015): 144-152. DOI. (C) 2015 American Pain Society. Used with permission. 


\title{
The Current State of Physical Therapy Pain Curricula in the United States: A Faculty Survey
}

\author{
Marie K. Hoeger Bement \\ Department of Physical Therapy, Marquette University, \\ Milwaukee, WI \\ Kathleen A. Sluka \\ Department of Physical Therapy and Rehabilitation Science, Pain \\ Research Program, Carver College of Medicine, \\ University of Iowa, \\ Iowa City, Iowa
}

\begin{abstract}
Insufficient pain education is problematic across the health care spectrum. Recent educational advancements have been made to combat the deficits in pain education to ensure that health care professionals are proficient in assessing and managing pain. The purpose of this survey was to determine the extent of pain education in current Doctorate of Physical Therapy schools in the United States, including how pain is incorporated into the curriculum, the amount of time spent teaching about pain, and the resources used to teach about pain. The survey consisted of 10 questions in the following subject areas: basic science mechanisms and concepts about pain, pain assessment, pain management, and adequacy of pain curriculum.
\end{abstract}

Journal of Pain, Vol 16, No. 2 (2015, February): pg. 144-152. DOI. This article is C Elsevier and permission has been granted for this version to appear in e-Publications@Marquette. Elsevier does not grant permission for this article to be further copied/distributed or hosted elsewhere without the express permission from Elsevier. 
NOT THE PUBLISHED VERSION; this is the author's final, peer-reviewed manuscript. The published version may be accessed by following the link in the citation at the bottom of the page.

The overall response was $77 \%(167 / 216)$ for the first series of responses of the survey (Question 1), whereas 62\% completed the entire survey (Questions $2-10$ ). The average contact hours teaching about pain was $31 \pm 1.8$ (mean \pm standard error of the mean) with a range of 5 to 115 hours. The majority of schools that responded covered the science of pain, assessment, and management. Less than $50 \%$ of respondents were aware of the Institute of Medicine report on pain or the International Association for the Study of Pain guidelines for physical therapy pain education. Only $61 \%$ of respondents believed that their students received adequate education in pain management. Thus, this survey demonstrated how pain education is incorporated into physical therapy schools and highlighted areas for improvement such as awareness of recent educational advancements.

Perspective: This article demonstrates how pain education is incorporated into physical therapy curricula within accredited programs. Understanding the current structure of pain education in health professional curriculum can serve as a basis to determine if recent publications of guidelines and competencies impact education.

Key words: Pain; physical therapy; education

More than 100 million adults in America suffer from chronic pain, costing over $\$ 600$ billion per year in health care expenditures and lost wages. $\underline{13}$ and $\underline{17}$ An inadequate understanding and management of pain is rapidly becoming a public health problem. Mismanagement of acute pain can delay healing, resulting in long-lasting changes to the peripheral and central nervous systems and consequently chronic pain. $\underline{6}$ Likewise, insufficient knowledge of chronic pain mechanisms and management can further create major human and economic costs for patients, families, and society. ${ }^{12}$ In 2010 , the International Pain Summit, an advocacy event of the International Association for the Study of Pain (IASP), endorsed the Declaration of Montreal, which stated that all people have the right to pain management by

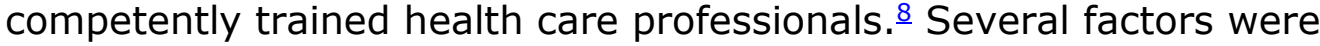
outlined regarding the current inadequacies of pain management, including deficits in knowledge by pain practitioners.

In 2011, the Institute of Medicine (IOM), which is an independent nonprofit organization that provides advice on national issues relating to health and medicine, complemented the Declaration of Montreal by highlighting the need for a cultural transformation in relieving pain in America. $\frac{17}{}$ The IOM report was developed in collaboration with the United States Department of Health and Human

Journal of Pain, Vol 16, No. 2 (2015, February): pg. 144-152. DOI. This article is @ Elsevier and permission has been granted for this version to appear in e-Publications@Marquette. Elsevier does not grant permission for this article to be further copied/distributed or hosted elsewhere without the express permission from Elsevier. 
Services through the National Institutes of Health to investigate pain as a public health problem. Specific entities identified to partake in this transformation were health care providers and health care professional associations. Similar to the Declaration of Montreal, education challenges were discussed in part to address insufficient pain knowledge for both undergraduate and graduate training programs. These educational challenges extend to physical therapists, as the IOM reported that physical therapists have a history of not being adequately prepared to provide pain management. $\underline{17}(\mathrm{p} .207)$ The report noted the nominal hours spent on pain education but did not specify specific content areas that were lacking.

The insufficiencies in pain education are problematic across the health care spectrum and include the following: medicine, dentistry, occupational therapy, nursing, pharmacy, and physical therapy $(\underline{\mathrm{PT}}) . \underline{.}$, $\underline{16}, \underline{17}, \underline{22}, \underline{29}, \underline{33}$ and $\underline{35}$ In a 1991 survey of orthopedic physical therapists, $72 \%$ reported that their entry-level pain education was very inadequate or less than adequate; this may explain why $96 \%$ preferred not to work with patients with chronic pain. $\frac{36}{A}$ survey for pre-licensure pain curricula in Canada reported that students of physical therapy receive 2.5 times more pain content than students of medicine (42 and 16 hours, respectively) but less than half that of students of veterinary medicine ( 87 hours). $\frac{35}{\text { In a }} 2001$ faculty survey on pain education in accredited PT programs in North America, the modal amount of time was 4 hours. $\underline{28}$ Despite the nominal contact hours, most of the topics surveyed were reported as adequately taught except for pain across the life span (especially children and elderly) and cognitive behavioral approaches. $\underline{28}$

Recent educational advancements have been made to combat the deficits in pain education to help ensure that health care professionals are proficient in assessing and managing pain. IASP developed a task force that consisted of a group of physical therapists worldwide with expertise in pain. $\underline{18}$ This task force established recommendations on pain curricula specifically for physical therapists. This curriculum was based on the 3 principles identified from the Declaration of Montreal: 1) access to pain management without discrimination; 2) acknowledgement of their pain and being informed about how it can be assessed and managed; and 3) appropriate assessment and treatment of the pain by adequately trained health

Journal of Pain, Vol 16, No. 2 (2015, February): pg. 144-152. DOI. This article is (C) Elsevier and permission has been granted for this version to appear in e-Publications@Marquette. Elsevier does not grant permission for this article to be further copied/distributed or hosted elsewhere without the express permission from Elsevier. 
care professionals. $\underline{8}$ The task force recommended that pain curricula be taught as an independent course for students with a background in anatomy, physiology, and kinesiology. The 4 main components of the curriculum included the following: 1) multidimensional nature of pain;

2) pain assessment and measurement; 3) management of pain; and 4) clinical conditions.

Another recent educational advancement is the establishment of core pain management competencies. In 2013, an interprofessional committee developed core competencies in pain assessment and management for pre-licensure health professional education and included the following 4 categories: multidimensional nature of pain, pain assessment and measurement, management of pain, and context of pain management. 12 The competencies were established as a guide for health care educators to advance pain education and were intended to be flexible in order to meet the expertise of each profession, and we recently addressed how these competencies relate to PT education. $\underline{15}$

Based on the advancements in pain education, greater awareness of pain as a health care problem, and the integral role that PT plays in pain management, we developed a survey to assess the extent of pain education in current accredited PT schools in the United States. Additionally, the survey was designed to evaluate how pain was incorporated into the curriculum, the amount of time spent on pain, and the resources used to teach about pain.

\section{Methods}

\section{Subjects}

All accredited $\mathrm{PT}$ schools in the United States were the target population. The list of PT programs $(n=216)$ was obtained in October 2012 from the website of the Physical Therapist Centralized Application Service, which is a service of the American Physical Therapy Association (APTA) for students to use a single application that lists both participating and nonparticipating schools. Information regarding the questionnaire along with an electronic link to the questionnaire was sent to the program directors and/or faculty members at each program. Initially, the director was sent the e-mail with the survey link 
and instructions to complete the survey him/herself or to forward the e-mail to the most appropriate person. This message was sent to the director on 2 occasions. We asked that survey respondents include the name of their school so there could only be 1 response per school. If a director did not respond, the authors then reviewed the website of that PT program to identify the most suitable faculty member that listed pain as part of his/her content area to complete the questionnaire. Individualized e-mails were then sent to the faculty member with the survey link. Programs that did not respond were sent a minimum of 5 e-mail messages from October 2012 through January 2013. This study was exempt from institutional review board approval because the educational curriculum survey involved gathering information on normal educational practices (pain education) in an established educational setting (U.S. accredited PT programs). No identifiable data on any individual was collected in this survey-only the name of the school and the rank of the person filling out the survey were collected.

\section{Survey Instrument}

The main aim of the questionnaire was to determine the extent of pain education in PT schools. The authors have extensive experience in pain education in PT curricula, were part of the IASP task force on developing the IASP curriculum, were part of the interprofessional group that developed the pain competencies, and regularly teach about pain in PT curricula. The development of the survey was adapted and modified from the methods, topics, and questions of surveys by Murinson that addressed pain curriculum for medical students. $\underline{22}$ and $\underline{25}$ Our topics were similar to those of Mezei and Murinson $\underline{22}$ and highlighted in the IOM report on Pain¹: basic concepts and science of pain, pain assessment, and pain management. Our criteria for the development of the survey were similar to Murinson et al 25 and based on the following: consultation of pain experts, completion of preliminary testing, and incorporation of IASP pain curriculum guidelines.

We consulted pain experts in the respective national organizations who identified concepts, topics, and questions for the survey. Pain experts were identified through the Pain Special Interest Group (Orthopedic Section in APTA), membership in pain organizations

Journal of Pain, Vol 16, No. 2 (2015, February): pg. 144-152. DOI. This article is @ Elsevier and permission has been granted for this version to appear in e-Publications@Marquette. Elsevier does not grant permission for this article to be further copied/distributed or hosted elsewhere without the express permission from Elsevier. 
(eg, IASP and American Pain Society), and participation in the Interprofessional Pain Management Competency Program. All of the experts had a terminal degree (ie, MD or PhD) and taught pain education across or within a specific discipline including PT, nursing, medicine, psychology, and pharmacy. These pain experts were consulted to generate questions or identify learning objectives pertaining to pain education of entry-level PT students while also incorporating the IASP curriculum guidelines. $\frac{18}{1}$ Furthermore, the development of the survey paralleled the recommendations by Murinson et al 22 to include a section on pain assessment to gauge the training in the clinical assessment of pain. It was also evident through development that pain was taught primarily within the existing curriculum, and few schools had an independent course dedicated to pain. We therefore wanted to capture the extent to which pain was covered within the PT curriculum and added questions about the total number of classroom hours that were devoted to pain science, assessment, and management.

The IASP curriculum guidelines are divided into 4 general areas: 1) multidimensional nature of pain that includes basic concepts and mechanisms of pain; 2) pain assessment and measurement; 3) management of pain that includes rehabilitation management and interdisciplinary management; and 4) clinical conditions, which is provided as a list of commonly treated conditions by physical therapists (guidelines). 18 The IASP guidelines have interprofessional pain education guidelines as well as discipline-specific guidelines including those for PT. $\stackrel{18}{ }$ The recently published entry-level pain competencies were similarly designed around these 4 general areas ${ }^{12}$ and purposely coordinated with the IASP curriculum guidelines. We therefore designed our survey around the IASP guidelines and divided our questions among general principles of pain and pain science, assessment of pain, and management of pain.

Pilot testing was done by sending the electronic survey link to a small group of pain experts $(n=5)$ within PT. The pilot testing was designed to test the appropriateness of the survey topics. The faculty members provided feedback that was used to improve clarity and expand the information that was obtained. The following changes were made due to pilot testing: 1) contact hours were added to better quantify pain education across multiple courses that may not show up

Journal of Pain, Vol 16, No. 2 (2015, February): pg. 144-152. DOI. This article is (C) Elsevier and permission has been granted for this version to appear in e-Publications@Marquette. Elsevier does not grant permission for this article to be further copied/distributed or hosted elsewhere without the express permission from Elsevier. 
in the semester hours; 2) membership to pain organizations was modified to include other organizations besides the Pain SIG within the Orthopedic Section of the APTA; and 3) the resources that were used for instructional purposes was modified to include specific examples (eg, Bonica's Pain Management). Following preliminary testing and on receiving the feedback, the study investigators determined final questions through consensus.

The final survey consisted of 10 questions in the following subject areas: basic science mechanisms and concepts about pain, pain assessment, pain management, and adequacy of pain curriculum. The survey was also designed to evaluate how pain was incorporated into the curriculum, the amount of time spent on pain, and the resources used to teach pain. The first question was a series of yes/no responses designed to assess how pain was incorporated into the PT curriculum as either a stand-alone course or integrated throughout the program. If a stand-alone course, we asked about number of semester hours. If integrated into the curriculum, we queried the total number of contact hours taught in the curriculum. Questions 2 to 10 were designed to evaluate what was taught in the curriculum and the number of hours spent on each subject. Question 2 asked about total number of classroom contact hours on a series of subjects that address pain science, assessment, and management. Questions 3 and 4 assessed if certain content areas were covered. Questions 5 to 10 assessed perception, knowledge, and resources used for pain education. The entire questionnaire is presented in the Appendix.

\section{Data Analysis}

Descriptive analyses of the responses were compiled and reported. For institutions, we categorized them as located in the northeast, south, midwest, or west; as research, liberal arts, or other oriented universities; or as public or private. Research or liberal arts universities were defined by the school's self-report, and other included schools that could not be defined as either research oriented or liberal arts and were primarily health-related educational institutes. Data are presented as the average with standard error of the mean, mode, median, and range of responses. The number of in-classroom contact hours, instead of semester hours, for each topic was reported

Journal of Pain, Vol 16, No. 2 (2015, February): pg. 144-152. DOI. This article is @ Elsevier and permission has been granted for this version to appear in e-Publications@Marquette. Elsevier does not grant permission for this article to be further copied/distributed or hosted elsewhere without the express permission from Elsevier. 
because pain is frequently integrated throughout the curriculum. We further report the percentage of respondents for individual topics. Data were organized and reported in 3 main categories of pain: science, assessment, interventions/management, which was modeled after the IASP curriculum guidelines. Under the science and assessment categories, we assessed if a variety of areas were taught. Lastly, under the interventions and management category, we reported the number of contact hours spent on each intervention.

\section{Results}

The overall response rate for the pain questionnaire sent to accredited PT education programs in the United States was $76 \%$ (167/216) for Question 1 in the survey. A total of 153 (71\%) of the programs gave the total number of contact hours spent on pain education. Several respondents reported that this question was difficult to assess because pain was integrated throughout the curriculum. All participants were expected to complete Questions 2 to 10 that assessed what was taught and the number of hours on each subject; however, only 62\% (137/216) answered this portion of the survey. Many reported that the material was integrated throughout the curriculum, and so they did not answer this portion of the survey. A similar number of program directors, professors, associate professors, assistant professors, and other faculty evenly distributed across different regions of the country completed both portions of the survey. Survey respondents varied across the spectrum from those in leadership positions, including deans, program directors, curriculum directors, or clinical education directors (29\%); professors (16\%); associate professors (21\%); assistant professors (31\%); and instructors (3\%). In comparing those who completed the survey to those that did not, an even distribution between groups was observed across different regions of the country except for the Midwest, which had more people completing the survey than not ( $20 \%$ vs $7 \%$ ). A similar distribution of research universities (76\% complete vs $80 \%$ incomplete) and public universities ( $57 \%$ both) was found.

Overall, respondents stated that total content on pain in their curriculum was $31 \pm 1.8$ (mean \pm standard error of the mean) contact hours. The number of contact hours ranged from 5 to 115 hours

Journal of Pain, Vol 16, No. 2 (2015, February): pg. 144-152. DOI. This article is @ Elsevier and permission has been granted for this version to appear in e-Publications@Marquette. Elsevier does not grant permission for this article to be further copied/distributed or hosted elsewhere without the express permission from Elsevier. 
across schools, with a mode of 10 contact hours. The number of contact hours was reported to help quantify the topics that are often covered in a variety of different courses. A total of $11 / 167(6 \%)$ respondents reported having an independent course focused on pain. Of those that have an independent pain course, the average number of semester hours was $2.3 \pm 1.3$ (range $1-5$; mode 2 ). Two schools had plans to add an independent pain course within the next year. By far the majority of schools that responded to the survey (140/167) have designated blocks of time to address pain, and these blocks are integrated throughout the curriculum.

Pain science, assessment, and management are incorporated throughout the curriculum by the majority of the schools that responded to the survey. The most time was spent on interventions and management ( $27.2 \pm 1.3$ hours [mean \pm standard error of the mean], median 24, range 6-84). This number of contact hours was followed by science of pain ( $9.5 \pm .38$ hours, median 8 , range $2-27$ ) and the least contact hours spent on assessment $(4.0 \pm .22$ hours, median 3, range $0-10$ ). Table 1 shows the average and total number of contact hours for a variety of topics.

Table 1. Contact Hours in Pain Science, Assessment, and Intervention and Management Categories

\section{Content Categories}

Pain science

Pain assessment

Pain intervention and management

Education and self-management strategies

Exercise therapy for pain control

Manual therapy for pain control

Electrical agents for pain control (TENS and IFC)

Thermal agents for pain control

Psychological management

Physician management

Multidisciplinary (interdisciplinary)

management

Abbreviations: SEM, standard error of the mean; TENS, transcutaneous electrical nerve stimulation; IFC, interferential current.

Within the pain science category, the majority of schools addressed all areas: pain pathways (97\%), acute versus chronic pain
Mean \pm SEM Median Mode Range

$\begin{array}{llll}9.5 \pm .38 & 8 & 6 & 2-27 \\ 4.0 \pm .22 & 3 & 2 & 0-10 \\ 27.2 \pm 1.3 & 24 & 16 & 6-84 \\ 3.2 \pm .19 & 3 & 2 & 0-10 \\ 3.9 \pm .25 & 3 & 2 & 0-10 \\ 4.4 \pm .26 & 3 & 2 & 0-10 \\ 4.6 \pm .23 & 4 & 2 & 0-10 \\ 3.9 \pm .23 & 3 & 2 & 0-10 \\ 2.7 \pm .17 & 2 & 2 & 0-10 \\ 2.2 \pm .14 & 2 & 2 & 0-10 \\ 2.3 \pm .14 & 2 & 2 & 0-3\end{array}$

Journal of Pain, Vol 16, No. 2 (2015, February): pg. 144-152. DOI. This article is (C) Elsevier and permission has been granted for this version to appear in e-Publications@Marquette. Elsevier does not grant permission for this article to be further copied/distributed or hosted elsewhere without the express permission from Elsevier. 
$(97 \%)$, biopsychosocial model $(95 \%)$, peripheral sensitization ( $84 \%)$, central sensitization $(87 \%)$, cortical pain processing $(85 \%)$, central inhibition (85\%), and neurotransmitters and receptors (93\%) (Table 2).

Table 2. Percentage of Respondents That Cover Specific Content Areas for the Science and Assessment Categories

Science Category

\begin{tabular}{|c|c|c|c|}
\hline Topic & \% Covered & Topic & $\%$ Covered \\
\hline Gate control theory & 95 & Subjective pain scales & 99 \\
\hline Biopsychosocial model & 95 & Pain-specific questionnaires & 83 \\
\hline Acute vs chronic pain & 97 & $\begin{array}{l}\text { Disease-specific } \\
\text { questionnaires }\end{array}$ & 91 \\
\hline Pain pathways & 97 & Functional assessments & 86 \\
\hline Peripheral sensitization & 84 & Psychological assessments & 80 \\
\hline Central sensitization & 87 & Pain across the life span & 68 \\
\hline Cortical processing & 85 & & \\
\hline Central inhibition & 85 & & \\
\hline $\begin{array}{l}\text { Neurotransmitters and } \\
\text { receptors }\end{array}$ & 93 & & \\
\hline
\end{tabular}

Fewer schools taught peripheral and central sensitization, cortical pain processing and central inhibition than pain pathways, acute versus chronic pain, and theories of pain (gate control and biopsychosocial model). These data show that the great majority of programs that responded to the survey are covering pain mechanisms and theories.

The highest response rate was with pain assessment. Almost all of the programs that responded ( $99 \%)$ teach subjective pain intensity rating scales such as the numerical rating scale or the visual analog scale. Eighty-three percent of respondents teach pain-specific questionnaires, which would include the Brief Pain Inventory $\underline{7}$ or McGill Pain Questionnaire, $\underline{21}$ whereas $91 \%$ of respondents teach diseasespecific questionnaires like the Oswestery $\underline{10}$ or the Fibromyalgia Impact Questionnaire. ${ }^{4}$ Functional measures such as the 6-minute walk test are covered by $86 \%$ of the respondents. Psychosocial questionnaires incorporating pain catastrophizing, depression, or anxiety are addressed by $81 \%$ of respondents. The lowest coverage was in pain assessment across the life span (68\%).

Journal of Pain, Vol 16, No. 2 (2015, February): pg. 144-152. DOI. This article is (C) Elsevier and permission has been granted for this version to appear in e-Publications@Marquette. Elsevier does not grant permission for this article to be further copied/distributed or hosted elsewhere without the express permission from Elsevier. 
Less than 50\% were aware of the IOM report on pain in 2011 $(48 \%)$ or the IASP guidelines for PT pain education (46\%). Sixty-one percent of respondents believed their students received adequate education in pain management. Of the respondents, $23 \%$ were involved in a pain specialty organization such as the American Pain Society $(.04 \%)$, the International Association for the Study of Pain $(1 \%)$, the American Academy of Pain Physicians (.01\%), or the Special Interest Group on Pain Management of the Orthopedic Section of the APTA (13\%). Although the majority of respondents used a variety of resources for education on pain management, the most commonly used books were Pain Mechanisms and Management for the Physical Therapist 30 (25/137; 18\%), Textbook of Pain 20 (23/137; 17\%), Explain Pain 5 (9/137; 7\%), and Bonica's Management of Pain 11 $(6 / 137 ; 4 \%)$. Also, highly cited were use of original literature and chapters on pain in other textbooks.

\section{Discussion}

The main purpose of this survey was to identify how pain education was incorporated into PT schools in the United States of America. Our results add to the paucity of information regarding pain education in PT. In particular, there are minimal data available and include 2 surveys published more than 10 and 20 years ago. $\underline{28}$ and $\underline{36} \mathrm{~A}$ more recent survey was published based on Canadian prelicensure pain curricula in health science faculties. $\frac{35}{5}$ The current study highlights how pain is taught in PT curricula. In particular, the majority of programs that responded instruct their students on pain mechanisms and theories $(>84 \%)$. The amount of time spent on pain teaching has evolved, with the current survey showing a modal of 10 hours and an average of 31 contact hours. Although a direct comparison is not possible, the amount of time appears to be an improvement compared to the Scudds' survey $\underline{28}$ that reported a modal of 4 hours spent on pain content but is less than Canadian PT students that averaged 41 hours. $\frac{35}{}$

Despite this increased coverage of pain, the survey highlighted areas for improvement; only $63 \%$ of responding schools believed that their students received adequate instruction in pain management. Specific to pain assessment, pain across the life span was the weakest

Journal of Pain, Vol 16, No. 2 (2015, February): pg. 144-152. DOI. This article is (c) Elsevier and permission has been granted for this version to appear in e-Publications@Marquette. Elsevier does not grant permission for this article to be further copied/distributed or hosted elsewhere without the express permission from Elsevier. 
component, with $69 \%$ of schools covering this information. These results are in parallel with the Scudds' survey in which the majority of responding faculty reported that pain in the elderly (57\%) and in children (76\%) was not adequately covered. $\underline{28}$ These results suggest that not all PT programs adequately provide pain education in their curriculum, especially pain assessment and management in the young and old.

Ensuring that PT students receive adequate instruction in pain mechanisms and management would likely result in improved patient outcomes and lower health care costs. $\underline{3}, \underline{31}$ and $\underline{32}$ Specific to PT, education of physical therapists in psychosocial risk factors and pain improved disability outcomes when compared to physical therapists who did not receive the education. $\underline{6}$ and $\underline{27}$ Further, there is a strong body of literature supporting the use of exercise for almost all pain conditions $\underline{23}$ and a growing body of literature showing the effectiveness of education of the patient on the science of pain, providing support for the incorporation of these concepts in PT pain curricula. $\underline{19}, \underline{24}, \underline{26}$ and $\underline{34}$ Further, Nijs et al $\underline{26}$ recommend assessing central sensitization in patients with musculoskeletal pain as part of the clinical examination to develop appropriate treatments and gauge treatment response. Though not investigated in this study, students with a strong pain foundation may have better patient outcomes through their improved ability to provide an evidence-based treatment, as supported by a prior study with physical therapists. $\underline{27}$

To help students develop a strong pain background, there were a variety of resources utilized, with none of the listed resources being used by the majority of respondents. Less than $50 \%$ of respondents were aware of the IASP curriculum guidelines for pain education or the IOM report on pain. This lack of awareness may be related to the low percentage of physical therapists who are members of pain specialty organizations such as the IASP (1\%). Specific IASP recommendations included that pain curriculum be taught as an independent course for students with an established background in anatomy, physiology, and kinesiology. We further suggest that pain be integrated throughout the curriculum across practice domains. $\frac{15}{2}$ The results of our survey indicated that approximately $8 \%$ of responding schools have an independent pain course, which is comparable to the 2001 survey that reported 11/107 PT programs had a separate pain course. $\underline{28}$

Journal of Pain, Vol 16, No. 2 (2015, February): pg. 144-152. DOI. This article is (C) Elsevier and permission has been granted for this version to appear in e-Publications@Marquette. Elsevier does not grant permission for this article to be further copied/distributed or hosted elsewhere without the express permission from Elsevier. 
The IOM report 1 recognized that education is a central component to achieve the cultural transformation that is needed to better understand and treat pain. The 3 main educational recommendations were: 1) expand and redesign education program to transform the understanding of pain; 2) improve curriculum and education for health care professionals; and 3) increase the number of health professionals with advanced expertise in pain care. Additional considerations to meet the education challenges include standardized pain curriculum requirements through accreditation groups and testing of pain knowledge and clinical competency with licensure examination. For example, incorporating a standardized curriculum would help address the disparity in pain education hours that occurs across schools (6-123 contact hours) thereby ensuring that all entry level physical therapists have the necessary expertise to provide adequate pain management to their patients.

Other resources have been or are being developed in direct response to the IOM report and the IASP curriculum guidelines. Recently, interprofessional pain management competencies were developed and published. We have recently described how these competencies can be integrated into PT curricula through learning activities and outcome assessment as they represent the expectation of minimal capabilities in providing comprehensive pain management. $\underline{12}$ and $\underline{15}$ Another resource has been introduced through the National Institutes of Health Pain Consortium, which designated Centers of Excellence in Pain Education (CoEPEs) (http://www.nih.gov/news/health/may2012/nih-21.htm). Twelve CoEPEs were identified and provided funding to develop interprofessional pain education curriculum and materials to be shared nationally. 9 Conclusions of a survey of prelicensure health sciences programs from 1 of the CoEPEs recommended incorporating more advanced teaching methods, including problem-based and team-based learning. Integrating the core competencies and recommendations by the CoEPEs within the foundation of PT education, will provide physical therapists with the core knowledge to stand with all health professions engaged in comprehensive pain management. $\underline{15}$

Although the inadequacies of pain education have been frequently cited, $\underline{8}$ and $\underline{17}$ there are limited recommendations for pain curriculum across the health care spectrum, especially in PT, and 
therefore the current survey relied on the IASP guidelines. This survey was not designed, however, to assess the quality of the pain education. For example, it is unclear if the significant gains in both basic and clinic science are being adequately incorporated. $\underline{2}$ and $\underline{14}$ The results of this survey may be used as the foundation for future studies to identify whether the incorporation of these newest guidelines and competencies translates to better clinical outcomes and to examine the quality of pain education. Further investigation is warranted in which pain knowledge and competencies are assessed in PT programs, including how patients with pain are incorporated into the curriculum. Specifically, more qualitative or mixed methods approaches may be useful to provide insight into the quality of pain education in PT programs. It is difficult to capture the adequacy of pain education and management approaches being taught in PT curricula with a quantitative survey alone. Future information should address not only the total number of hours, but should also provide an opportunity for more open-ended questions. Further it might be useful to not only survey the programs themselves from faculty surveys but to also survey recent graduates from these programs to assess their treatment approaches to pain.

\section{Limitations}

Data on the qualifications of the respondent, such as whether he/she was the most appropriate individual to answer pain curriculum questions, is not known. Another limitation is that several respondents indicated it was difficult for a single respondent to complete the survey because pain education is typically integrated throughout the curricula and includes multiple courses; the number of contact hours spent on pain education therefore is likely underestimated because content related to specific clinical conditions was not included in the survey. Further, the overall response rate for the pain questionnaire sent to accredited PT education programs in the United States was $77 \%$ for the first series of questions but only $62 \%$ for the second series of more detailed questions. Although there was no detectable pattern to those who answered all questions and those who only answered the first question, the data could be skewed because of different results based on the characteristics of nonresponders. This potential bias is inherent in all survey data and unavoidable. We employed a number of

Journal of Pain, Vol 16, No. 2 (2015, February): pg. 144-152. DOI. This article is @ Elsevier and permission has been granted for this version to appear in e-Publications@Marquette. Elsevier does not grant permission for this article to be further copied/distributed or hosted elsewhere without the express permission from Elsevier. 
methods to obtain a good response rate, as outlined in the methods. This included an introduction about the importance of the survey, the IOM report, and prior data on pain education. However, we recognize that this could have biased the outcomes as investigators may have been more apt to perform a more thorough examination of their curriculum or have read the IOM report. On the other hand, it could have improved the thoroughness with which the curriculum was evaluated when compared to past surveys. Our response rate $(62 \%)$ is above the average response rates of 40 to $50 \%$ for similar surveys (needs assessment, impact evaluation) and is considered a good to excellent return for an e-mail survey..$^{1}$

\section{Conclusion}

This survey demonstrated how pain is incorporated into $\underline{P T}$ curricula. To stay current in pain education, PT programs should be aware of the latest educational advancements, including the IOM report, IASP guidelines, and pain competencies. Given the integral role of primary care providers in providing adequate pain management, improving pain education should be an important consideration in programs across health care disciplines.

\section{Appendix. Pain Survey}

\section{Introduction}

In July 2011, the Institute of Medicine (IOM) released a report on pain. In this report, it was recommended that primary education programs in all disciplines increase their curriculum to focus on pain management using a biopsychosocial and interdisciplinary approach.

The report also referred to a survey conducted in 1991 by the Orthopedic Section of the APTA that showed an average of 4 hours instruction in accredited PT programs in North America. Significant awareness and advancement has occurred since the survey, leading us to reevaluate the current state of education with respect to pain in Doctorate of Physical Therapy curriculum in the United States. $\underline{33}$

Journal of Pain, Vol 16, No. 2 (2015, February): pg. 144-152. DOI. This article is @ Elsevier and permission has been granted for this version to appear in e-Publications@Marquette. Elsevier does not grant permission for this article to be further copied/distributed or hosted elsewhere without the express permission from Elsevier. 
NOT THE PUBLISHED VERSION; this is the author's final, peer-reviewed manuscript. The published version may be accessed by following the link in the citation at the bottom of the page.

The purpose of this is to determine how pain is addressed in current Doctorate of Physical Therapy curriculum in the United States. We are asking that you or one of your professors most closely associated with the curriculum fill out the following short survey. This survey should take no more than 10 to 15 minutes to complete.

\section{Questions}

1. Do you have a free-standing pain mechanisms/management course? (yes/no)

1a. If Yes-how many semester hours?

1b. If No-do you have plans to institute a pain mechanisms/management course in the next year?

1b.1. If Yes-how many semester hours?

1b.2. If No-do you have a designated block of time to address pain mechanisms/management?

1b.2.a. If Yes-what course(s)?

1b.2.b. If Yes-how many total contact hours?

1.b.2.c. If No-how many hours are dedicated to pain mechanisms assessment and management?

2. How many contact (lecture and lab) hours do you cover in your curriculum? (Response was a drop-down menu with 0-10 contact hours)

a. The science of underlying pain and analgesia

b. Pain assessment

c. Differences in acute and chronic pain

d. Biopsychosocial model of pain

e. Education and self-management strategies for the pain patient

f. Exercise therapy for pain control

g. Manual therapy for pain control

h. Electrical agents for pain control (TENS, IFC)

i. Thermal agents for pain control

j. Psychological management of the pain patient

$\mathrm{k}$. Physician management of the pain patient

I. Multidisciplinary (interdisciplinary) management of the pain patient

3. If the science underlying pain and analgesia is covered in your curriculum, what is included? (check all that apply)

$\circ$ Gate control theory of pain 
NOT THE PUBLISHED VERSION; this is the author's final, peer-reviewed manuscript. The published version may be accessed by following the link in the citation at the bottom of the page.

- Pain pathways

- Peripheral sensitization

- Central sensitization

o Central Inhibition

- Neurotransmitters and receptors

4. If pain assessment is covered in your curriculum what is included (check all that apply)

- Subjective pain intensity such as the numerical rating scale or visual analog scales

- Pain-specific questionnaires such as the Brief Pain Inventory

- Disease-specific questionnaires such as the Oswestry or Fibromyalgia Impact Questionnaire

o Functional measures such as the 6-minute walk test or functional reach test

- Psychosocial questionnaires such as pain catastrophizing, fear avoidance, depression, or anxiety.

- Assessment across the life span: pediatrics to geriatrics

5 . Are you aware of the IOM report on pain published in July 2011? (yes/no)

6. Are you aware of the International Association for the Study of Pain's (IASP's) guidelines for physical therapy education on pain? (yes/no)

7. Do you believe your students receive adequate instruction in pain management? (yes/no)

8. How many total instruction hours on pain and pain management do your students receive in the entire program? (open-ended question)

9. Is the person teaching the pain curriculum a member of any the following pain organizations? (check all that apply)

a. American Pain Society

b. International Association for the Study of Pain

c. American Academy of Pain Physicians

d. Special Interest Group on Pain Management of the Orthopedic

Section of the American Physical Therapy Association

10. What resources are you using for instructional purposes on pain management? (check all that apply)

a. Pain Mechanisms and Management for the Physical Therapist, Sluka KA, IASP Press

b. Textbook of Pain, Melzack and Wall

c. Bonica's Pain Management

Journal of Pain, Vol 16, No. 2 (2015, February): pg. 144-152. DOI. This article is @ Elsevier and permission has been granted for this version to appear in e-Publications@Marquette. Elsevier does not grant permission for this article to be further copied/distributed or hosted elsewhere without the express permission from Elsevier. 
NOT THE PUBLISHED VERSION; this is the author's final, peer-reviewed manuscript. The published version may be accessed by following the link in the citation at the bottom of the page.

d. Other-please list

\section{References}

1 Archer TM. Response rates to expect from web-based surveys and what to do about it. J Extension [Online], 46(3), June 2008. Available at: http://www.joe.org/joe/2008june/rb3.php

2 A.I. Basbaum, D.M. Bautista, G. Scherrer, D. Julius. Cellular and molecular mechanisms of pain. Cell, 139 (2009), pp. 267-284

3 Belfer I: Nature and nurture of human pain. Scientifica, vol 2013, Article ID 415279, 19 pages, 2013. http://dx.doi.org/10.1155/2013/415279

4 C.S. Burckhardt, S.R. Clark, R.M. Bennett. The Fibromyalgia Impact Questionnaire: Development and validation. J Rheumatol, 18 (1991), pp. 728-734

${ }_{5}$ D.S. Butler, L.S. Moseley. Explain Pain. Noigroup Publications, Adelaide (2003)

6 M.D. Cheatle, C.P. O'Brien. Opioid therapy in patients with chronic noncancer pain: Diagnostic and clinical challenges. Adv Psychosom Med, 30 (2011), pp. 61-91

7 C.S. Cleeland. Measurement of pain by subjective report. C.R. Chapman, J.D. Loeser (Eds.), Issues in Pain Measurement, Raven Press, New York (1989), pp. 391-403

8 M.J. Cousins, M.E. Lynch. The Declaration Montreal: Access to pain management is a fundamental human right. Pain, 152 (2011), pp. 2673-2674

9 A.Z. Doorenbos, D.B. Gordon, D. Tauben, J. Palisoc, M. Drangsholt, T. Lindhorst, J. Danielson, J. Spector, R. Ballweg, L. Vorvick, J.D. Loeser. A blueprint of pain curriculum across prelicensure health sciences programs: One NIH pain consortium center of excellence in pain education (CoEPE) experience. J Pain, 12 (2013), pp. 1533-1538

10 J.C. Fairbank, J. Couper, J.B. Davies, J.P. O'Brien. The Oswestry Low Back Pain Disability Questionnaire. Physiotherapy, 66 (1980), pp. 271-273

11 S.M. Fishman, J.C. Ballantyne, J.P. Rathmell. Bonica's Management of Pain. Lippincott Williams \& Wilkins, Baltimore (2009)

12 S.M. Fishman, H.M. Young, E. Lucas Arwood, R. Chou, K. Herr, B.B. Murinson, J. Watt-Watson, D.B. Carr, D.B. Gordon, B.J. Stevens, D. Bakerjian, J.C. Ballantyne, M. Courtenay, M. Djukic, I.J. Koebner, J.M. Mongoven, J.A. Paice, R. Prasad, N. Singh, K.A. Sluka, B. St Marie, S.A. Strassels. Core competencies for pain management: Results of an interprofessional consensus summit. Pain Med, 14 (2013), pp. 971981

13 D.J. Gaskin, P. Richard. The economic costs of pain in the United States. J Pain, 13 (2012), pp. 715-724

Journal of Pain, Vol 16, No. 2 (2015, February): pg. 144-152. DOI. This article is @ Elsevier and permission has been granted for this version to appear in e-Publications@Marquette. Elsevier does not grant permission for this article to be further copied/distributed or hosted elsewhere without the express permission from Elsevier. 
NOT THE PUBLISHED VERSION; this is the author's final, peer-reviewed manuscript. The published version may be

accessed by following the link in the citation at the bottom of the page.

14 R.J. Gatchel, Y.B. Peng, M.L. Peters, P.N. Fuchs, D.C. Turk. The biopsychosocial approach to chronic pain: Scientific advances and future directions. Psychol Bull, 133 (2007), pp. 581-624

15 M.K. Hoeger-Bement, B.J. St. Marie, T.M. Nordstrom, N. Christensen, J.M. Mongoven, I.J. Koebner, S.M. Fishman, K.A. Sluka. An interprofessional consensus of core competencies for prelicensure education in pain management: Curriculum application for physical therapy. Phys Ther, 94 (2014), pp. 451-465

16 J. Hunter, J. Watt-Watson, M. McGillion, L. Raman-Wilms, L. Cockburn, L. Lax, J. Stinson, A. Cameron, T. Dao, P. Pennefather, M. Schreiber, L. Librach, T. Kavanagh, A. Gordon, N. Cullen, D. Mock, M. Salter. An interfaculty pain curriculum: Lessons learned from six years experience. Pain, 140 (2008), pp. 74-86

17 Institute of Medicine (U.S.). Committee on Advancing Pain Research Care and Education. Relieving Pain in America: A Blueprint for Transforming Prevention, Care, Education, and Research. National Academies Press, Washington, DC (2011)

18 International Association for the Study of Pain. Available at: http://www.iasppain.org/Education/CurriculaList.aspx?navItemNumber=647. Accessed December 2014

19 A. Louw, I. Diener, D.S. Butler, E.J. Puentedura. The effect of neuroscience education on pain, disability, anxiety, and stress in chronic musculoskeletal pain. Arch Phys Med Rehabil, 92 (2011), pp. 20412056

20 S. McMahon, M. Kolzenburg, I Tracey, D Turk. Wall and Melzack's Textbook of Pain. Elsevier, Philadelphia (2013)

21 R. Melzack. The McGill Pain Questionnaire: Major properties and scoring methods. Pain, 1 (1975), pp. 277-299

22 L. Mezei, B.B. Murinson. Johns Hopkins Pain Curriculum Development Team. Pain education in North American medical schools. J Pain, 12 (2011), pp. 1199-1208

23 G.L. Moseley. Evidence for a direct relationship between cognitive and physical change during an education intervention in people with chronic low back pain. Eur J Pain, 8 (2004), pp. 39-45

24 G.L. Moseley, M.K. Nicholas, P.W. Hodges. A randomized controlled trial of intensive neurophysiology education in chronic low back pain. Clin $\mathrm{J}$ Pain, 20 (2004), pp. 324-330

25 B.B. Murinson, V. Gordin, S. Flynn, L.C. Driver, R.M. Gallagher, M. Grabois. Recommendations for a new curriculum in pain medicine for medical students: Toward a career distinguished by competence and compassion. Pain Med, 14 (2013), pp. 345-350

Journal of Pain, Vol 16, No. 2 (2015, February): pg. 144-152. DOI. This article is @ Elsevier and permission has been granted for this version to appear in e-Publications@Marquette. Elsevier does not grant permission for this article to be further copied/distributed or hosted elsewhere without the express permission from Elsevier. 
NOT THE PUBLISHED VERSION; this is the author's final, peer-reviewed manuscript. The published version may be accessed by following the link in the citation at the bottom of the page.

26 J. Nijs, B. Van Houdenhove, R.A. Oostendorp. Recognition of central sensitization in patients with musculoskeletal pain: Application of pain neurophysiology in manual therapy practice. Man Ther, 15 (2010), pp. $135-141$

27 T. Overmeer, K. Boersma, E. Denison, S.J. Linton. Does teaching physical therapists to deliver a biopsychosocial treatment program result in better patient outcomes? A randomized controlled trial. Phys Ther, 91 (2011), pp. 804-819

28 R.J. Scudds, R.A. Scudds, M.J. Simmonds. Pain in the physical therapy (PT) curriculum: A faculty survey. Physiother Theory Pract, 17 (2001), pp. 239-256

29 R.M. Singh, S.L. Wyant. Pain management content in curricula of U.S. Schools of pharmacy. J Am Pharm Assoc, 43 (2003), pp. 34-40

30 K.A. Sluka. Mechanisms and Management of Pain for the Physical Therapist. IASP Press, Seattle (2009)

31 S.P. Thomas, M. Johnson. A phenomenologic study of chronic pain. Wet J Nurs Res, 22 (2000), pp. 683-705

32 J.A. Trafton, E.M. Oliva, D.A. Horst, J.D. Minkel, K. Humphreys. Treatment needs associated with pain in substance use disorder patients: Implications for concurrent treatment. Drug Alcohol Depend, 73 (2004), pp. 23-31

33 C.C. Upshur, R.S. Luckmann, J.A. Savageau. Primary care provider concerns about management of chronic pain in community clinic populations. J Gen Intern Med, 21 (2006), pp. 652-655

34 J. Van Oosterwijck, M. Meeus, L. Paul, M. De Schryver, A. Pascal, L. Lambrecht, J. Nijs. Pain physiology education improves health status and endogenous pain inhibition in fibromyalgia: A double-blind randomized controlled trial. Clin J Pain, 29 (2013), pp. 873-882

35 J. Watt-Watson, M. McGillion, J. Hunter, M. Choiniere, A.J. Clark, A. Dewar, C. Johnston, M. Lynch, P. Morley-Forster, D. Moulin, N. Thie, C.L. von Baeyer, K. Webber. A survey of prelicensure pain curricula in health science faculties in Canadian universities. Pain Res Manag, 14 (2009), pp. 439-444

36 M.S. Wolff, T.H. Michel, D.E. Krebs, N.T. Watts. Chronic pain-assessment of orthopedic physical therapists' knowledge and attitudes. Phys Ther, 71 (1991), pp. 207-214

M.K.H.B. receives research support from the National Institutes of Health. K.A.S. receives research funding from Medtronic, Inc, Grunenthal, and National Institutes of Health, research supplies (transcutaneous electrical nerve stimulation units/electrodes) provided by DJO, Inc, and royalties from IASP Press for book titled "Pain Mechanisms and Management for the Physical Therapist." She is a member of the advisory panel for IASP Press and secretary for the American Pain Society. She served as a member of the Task

Journal of Pain, Vol 16, No. 2 (2015, February): pg. 144-152. DOI. This article is @ Elsevier and permission has been granted for this version to appear in e-Publications@Marquette. Elsevier does not grant permission for this article to be further copied/distributed or hosted elsewhere without the express permission from Elsevier. 
NOT THE PUBLISHED VERSION; this is the author's final, peer-reviewed manuscript. The published version may be accessed by following the link in the citation at the bottom of the page.

Force to Develop Physical Therapy Pain Education Guidelines from the International Association for the Study of Pain and served on competency advisory committee for the Interprofessional Pain Management Competency Program.

Address reprint requests to Kathleen A. Sluka, PT, PhD, FAPTA, Department of Physical Therapy and Rehabilitation Science, 1-248 MEB, University of Iowa, Iowa City, IA 52242. 